\title{
H2BC5 Gene
}

National Cancer Institute

\section{Source}

National Cancer Institute. H2BC5 Gene. NCI Thesaurus. Code C116683.

This gene plays a role in the formation of nucleosomes. 